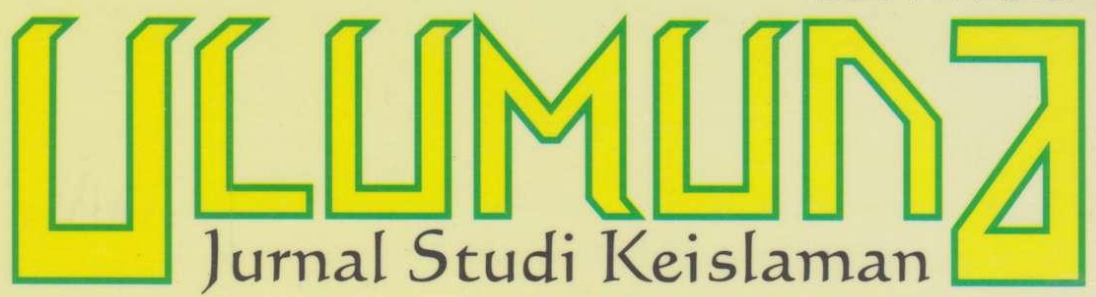

Volume XIV• Nomor 2• Desember 2010

TERAKREDITASI Berdasarkan SK Dirjen Dikti Depdiknas Nomor: 65a/DlKTl/Kep/2008

MENCERMATI EPISTEMOLOGI TASAWUF A. Khudori Soleh

EPISTEMOLOGI TASAWUF DALAM PEMIKIRAN FIQH AL-SYA'RÂNÎ Miftahul Huda

\title{
PEREMPUAN DALAM LINTASAN SEJARAH TASAWUF
} Sururin

GeRAKan PETANI BANTEN: STUDI TERHADAP KONFIGURASI SUFISME AWAL ABAD XIX Hamidah

IMPLEMENTASI NILAI-NILAI SUFISME DALAM TAREKAT NAQSYABANDIYAH

DI SULAWESI SELATAN

Hadarah Rajab

TAREKAT "SEMI MANDIRI": PROTOtIPE RItuAl MASYARAKAT PEDESAAN MADURA Imam Amrusi Jailani 
TRANSLITERASI

Artikel

A. Khudori Soleh Mencermati Epistemologi

Tasawuf • 227-248

Miftahul Huda Epistemologi Tasawuf dalam

Pemikiran Fiqh al-Sya'rani • 249-270

Mutawalli Teologi Sufistik

Syaikh al-Akbar Ibn 'Arabi • 271-298

Sururin Perempuan dalam Lintasan

Sejarah Tasawuf • 299-322

Hamidah Gerakan Petani Banten:

Studi terhadap Konfigurasi Sufisme

Awal Abad XIX • 323-340

Hadarah Rajab Implementasi Nilai-Nilai Sufisme

Tarekat Naqsyabandiyah

di Sulawesi Selatan • 341-368

Imam Amrusi Jailani Tarekat "Semi Mandiri”: Prototipe Ritual Masyarakat Pedesaan Madura • 369-388

Yusno Abdullah Otta Tasawuf dan Perubahan Sosial • 389-412

Tri Astutik Haryati\& Tasawuf dan Tantangan

Mohammad Kosim Modernitas • 413-428

\section{INDEKS}




\section{PEDOMAN TRANSLITERASI}

\begin{tabular}{|c|c|c|c|c|c|}
\hline Arab & & Latin & Arab & & Latin \\
\hline 1 & $=$ & $\mathrm{a}$ & ف & $=$ & $\mathrm{f}$ \\
\hline ب & $=$ & b & ق & $=$ & $q$ \\
\hline ت & $=$ & $\mathrm{t}$ & ك5 & $=$ & $\mathrm{k}$ \\
\hline$\dot{H}$ & $=$ & ts & J & $=$ & 1 \\
\hline ج & $=$ & j & 5 & $=$ & $\mathrm{m}$ \\
\hline$\tau$ & $=$ & $\underline{\mathrm{h}}$ & ن ن & $=$ & $\mathrm{n}$ \\
\hline$\dot{\tau}$ & $=$ & $\mathrm{kh}$ & و & $=$ & $\mathrm{w}$ \\
\hline د & $=$ & $\mathrm{d}$ & 。 & $=$ & $\mathrm{h}$ \\
\hline ذ & $=$ & $\mathrm{d} z$ & $\Leftrightarrow$ & $=$ & , \\
\hline J & $=$ & $\mathrm{r}$ & ي & $=$ & $\mathrm{y}$ \\
\hline j & $=$ & z & & & \\
\hline س & $=$ & $\mathrm{s}$ & & & \\
\hline ش & $=$ & sy & \multirow{2}{*}{\multicolumn{3}{|c|}{$\begin{array}{l}\text { Untuk Madd } \\
\text { dan Diftong }\end{array}$}} \\
\hline ص ص & $=$ & sh & & & \\
\hline ض ض & $=$ & $\mathrm{dl}$ & i & $=$ & â (a panjang) \\
\hline b & $=$ & th & إي - اي & $=$ & $\hat{1}$ (i panjang) \\
\hline ظ & $=$ & $\mathrm{zh}$ & أو - أو & $=$ & û (u panjang) \\
\hline$\varepsilon$ & $=$ & ' & او - - او & $=$ & aw \\
\hline$\dot{\varepsilon}$ & $=$ & gh & أي اي & $=$ & ay \\
\hline
\end{tabular}




\title{
GERAKAN PETANI BANTEN: STUDI TENTANG KONFIGURASI SUFISME AWAL ABAD XIX
}

\author{
Hamidah $^{*}$
}

\begin{abstract}
Sufism is an esoteric dimension of Islam, which differs from the outer aspect of Islam known as shari'a. This view did not emerge at the early time because Sufism was not regarded as the inner manifestation of Islam, as it is so now. Rather, it was seen as Islam itself. Tarekat in its initial phase constituted associations of people who wanted to escape from a worldly life. However, this orientation shifted since the associations broadened their roles into socio-political life by engaging in revolts against colonialism as it occurred in Banten in 1888. This peasant revolt movement was not an independent move without a significant contribution from the sufi brotherbood since actors in the revolt were members of tarekat. According to Banten Residen, almost all of the employees in bis office including police were the members of tarekat. One salient feature of the movement is concerned with the xenophobic spirit that rejected the presence of foreigners and advocated a boly war.
\end{abstract}

Abstrak: Sufisme merupakan dimensi batin atau esoteris Islam yang seringkali dibedakan dengan dimensi lahir atau eksoteris Islam yang lebih dikenal dengan syariah. Pada masa awal Islam, sufisme tidak dipandang sebagai sisi batin (terdalam) dari ajaran Islam sebagaimana yang terjadi pada masa sekarang. Melainkan ia dipandang sebagai Islam sendiri. Tarekat (sufisme), pada masa awal berdirinya, merupakan kumpulan jaringan massa yang cenderung menekankan eskatisme dan anti keduniaan. Kemudian perannya mengalami pergeseran menjadi dasar bagi berbagai kekuatan sosial politik termasuk Pemberontakan Petani Banten 1888. Gerakan Petani Banten 1888 tidak bisa dilepaskan dari latar belakang gerakan tarekat, karena banyak pelakunya tercatat sebagai pengikut tarekat; babkan menurut sinyalemen Residen Banten, seluruh pegawai sipil di sana, termasuk polisi, berada di bawah pengaruh para pemimpin agama yang notabene juga pengikut gerakan tarekat. Salah satu identitas gerakan semacam ini adalah xenophobia (anti orang asing) dan menggalakkan perang suci.

Keywords: Sufisme, Gerakan Tarekat, Tarekat Qadiriyah wa Naqsyabandiyah, Pemberontakan Petani, Xenophobia.

*Penulis adalah dosen pada Fakultas Dakwah dan Komunikasi IAIN Raden Fatah, Palembang. email: hmidah@yahoo.com 
SEBAGAI suatu ajaran, sufisme merupakan dimensi batin atau esoteris Islam yang seringkali dibedakan dengan dimensi lahir atau eksoteris Islam yang lebih dikenal dengan syariah. Sebagai gerakan, dalam sejarah dan perkembangannya, para sufi dapat dikategorikan kepada dua kelompok, yaitu: pertama, sufi individual yang terpanggil untuk mempraktekkan kehidupan asketis dan mistis yang menghasilkan karya-karya sufisme serta dikenal lewat karya tersebut oleh para sufi belakangan. Kadangkadang para sufi yang diikuti oleh sejumlah pengikut yang menganggapnya sebagai special figure yang dapat mengikat mereka pada suatu aliran tertentu, dan, kedua, para sufi yang diikat oleh suatu aliran tertentu dan merupakan suatu persaudaraan yang sering disebut dengan tarekat. Kadang-kadang suatu tarekat merupakan institusi semiformal yang bergerak di bidang sosial, ekonomi, dan bahkan politik.

Sufisme, dalam perkembangannya, merupakan dimensi Islam yang oleh sebagian orang dianggap kontroversial. Hakekat dan eksistensinya terkadang disalahpahami. Dalam perspektif teologis, ajaran-ajaran sufisme oleh beberapa kalangan, terutama golongan modernis, dipandang sebagai ajaran yang tidak berasal dari ajaran Islam murni sehingga penganutnya dapat menjadi musyrik. Sufisme dianggap bid'ah yang mengandung takhayul dan khurafat. Dalam perspektif sosiologis, sufisme yang mengajarkan kehidupan asketis dianggap menghambat pembangunan dan kemajuan zaman.

Menurut Zulkifli, tuduhan dan kritikan terhadap sufisme tersebut seringkali tidak beralasan. Tuduhan dan kritikan tersebut biasanya datang dari golongan yang tidak memahami sufisme secara komprehensif dan mendalam dan tidak melihatnya dari perspektif para sufi itu sendiri. ${ }^{1}$

Seyyed Hossein Nasr ${ }^{2}$ menyatakan bahwa dalam abad XIX dunia Islam diharu biru oleh dampak Barat bersamaan dengan

1 Zulkifli, Pemeliharaan dan Kesinambungan Tradisi Tasawuf Tarekat Sammaniyah di Palembang, makalah yang disampaikan pada Pertemuan Jaringan Pusat Penelitian IAIN/STAIN tanggal 18-19 Juni 1997 di IAIN Raden Fatah Palembang, 2.

${ }^{2}$ Seyyed Hossein Nasr, Tasawuf Dulu dan Sekarang (Jakarta: Pustaka Firdaus, 1994), 3. 
timbulnya gerakan-gerakan puritan, seperti gerakan-gerakan seperti gerakan rasionalis dan antimistik. Gerakan-gerakan itu timbul menentang tasawuf; tasawuf dikutuk hampir dalam segala segi yang oleh kalangan modernis pada waktu itu dirasakan menyimpang dari Islam.

Persoalan jatuhnya dunia Islam ke tangan penguasa Barat, kesalahannya dialamatkan kepada tasawuf dan dari situ muncullah suatu generasi orang-orang Islam yang kebaratbaratan, yang masih kita jumpai di banyak negeri Islam dewasa ini. Dengan ditunjang oleh para orientalis, gerakan ini berupaya menghidupkan kembali Islam dengan menolak segala aspek kerohanian dan metafisik ajaran-ajarannya.

Secara teologis, sesungguhnya tasawuf memiliki dasar yang kuat di dalam al-Qur'an, al-Sunnah, dan memiliki akar yang lebih kuat di dalam al-Qur'an dibandingkan dimensi syari'ah. Sufisme sebagai simbol kejumudan dan kepasifan juga merupakan kesimpulan yang over-generalization karena dalam banyak kasus di dunia muslim, para sufi dan pengikut tarekat berperan aktif dalam berjuang melawan kaum kolonial. Di Indonesia, beberapa tarekat merupakan kelompok masyarakat yang ditakuti pemerintah kolonial Belanda karena gerakan-gerakan pemberontakan yang mereka lakukan.

Hal demikian menjelaskan bahwa selain mempunyai fungsi keagamaan, tarekat-tarekat tertentu pun mempunyai kekuatan politik. Seikh-seikh tarekat yang karismatik akan dapat memainkan peranan pentingnya dalam merekrut massa dan dapat pula memainkan peranan penting dalam perpolitikan.

Terkait dengan peranan penting sufisme, menurut Martin, tarekat mengambil bagian dalam pemberontakan anti kolonial selama akhir abad XIX dan awal abad XX. Salah satu pemberontakan yang paling besar terhadap pemerintah Belanda terjadi di Banten (Jawa Barat) pada tahun 1888. Di sini tarekat Qadiriyah dan Naqsyabandiyah terlibat, walaupun mungkin secara tak langsung. Keterlibatan yang sama juga terjadi di Jawa Timur pada tahun 1903 yang berhubungan dengan pemberontakan yang bercorak mesianistik. Pemberontakan 
besar lainnya, yang disebabkan diberlakukannya pajak tembakau yang baru, pecah di Sumatera Barat pada tahun 1908. ${ }^{3}$

Meskipun demikian, tidak satu pun dari inisiatif untuk melancarkan pemberontakan itu berasal dari tarekat sendiri, tetapi apabila pemberontakan itu sudah meletus, tarekat menyediakan jaringan untuk melakukan komunikasi antara daerah dan mobilisasi, di samping teknik-teknik spiritualnya yang diyakini memberikan perlindungan magis.

Tulisan ini mencoba mengangkat persoalan tentang Gerakan Petani Banten: Studi terhadap Konfigurasi Sufisme Awal Abad XIX, yang menjelaskan tentang peran sufisme; gerakan petani Banten; gerakan petani banten sebagai realisasi peran sufisme.

\section{Peran Sufisme}

Pada masa awal Islam, sufisme tidak dipandang sebagai sisi batin (terdalam) dari ajaran Islam sebagaimana yang terjadi pada masa sekarang. Melainkan ia dipandang sebagai Islam sendiri. Kalangan sufi mengatakan: "pada awalnya sufisme merupakan realitas tanpa nama, sedang yang sekarang ini merupakan suatu nama tanpa realitas". Bagi kalangan sufi, guru sufi yang terbesar dan guru yang sejati tidak lain adalah Nabi Muhammad saw. sendiri yang mengajarkan ajaran esoteris Islam kepada para sahabat, yang pada masa berikutnya mereka menjadi generasi penerus. Dari sumber inilah, para sufi mewarisi inspirasi dan ajaran-ajaran para sahabat. Dan para sahabat juga menyampaikan anugerah atau berkah spiritual yang diterima Nabi Muhammad saw. dari Tuhan pada masa awal risalahnya dan kemudian disampaikan kepada para sahabatnya melalui bay'ah al-ridlwân (sumpah kesetiaan) yang berlangsung di Hudaybiyah. ${ }^{4}$

Sufisme merupakan sains tentang pengetahuan secara langsung mengenai Tuhan. Ajaran dan metodenya berasal dari al-Qur'an dan ajaran Islam. Dalam perkembangannya, secara historis, kalangan sufi mengelompokkan diri ke dalam organisasi yang dinamakan thawâif, thâifah atau thurîq, tharîah. Thurûq merupakan kumpulan yang dibentuk mengelilingi seorang guru

${ }^{3}$ Martin van Bruinessen, Kitab Kuning: Pesantren dan Tarekat (Bandung: Mizan, 1994), 198.

${ }^{4}$ Cyril Glasse, Ensiklopedi Islam (Jakarta: Rajawali Press, 2002), 370. 
sufi yang mengadakan pertemuan untuk mengadakan pengajaran spiritual dalam sebuah tempat pertemuan yang dalam beberapa bahasa digunakan sejumlah istilah, dzamiyah, khanaqah.

Tarekat, pada masa awal berdirinya, merupakan kumpulan jaringan massa yang cenderung menekankan eskatisme dan anti keduniaan. Namun, perannya mengalami pergeseran menjadi dasar bagi berbagai kekuatan sosial politik; sejak dari gerakan Safarid di Persia, Murabitun dan Muwahidun di Afrika Utara, Naqsyabandiyah di India pada masa pemerintahan Akbar, sampai kepada gerakan Diponegoro dan Pemberontakan Petani Banten 1888.

Azyumardi Azra mencatat bahwa tarekat sebelum abad XII cenderung menekankan eskatisme dan anti keduniaan, tetapi sejak abad XII, ia memberikan kerangka organisasi yang cukup solid bagi gerakan sosial. Kini bukan hanya kaum awam yang tersedot ke dalam organisasi sufi, tetapi juga kelompokkelompok tentara, seniman, dan lain-lain. Semua kelompok ini disatukan oleh jaringan afiliasi tarekat ke dalam lingkungan masyarakat lebih luas. Seorang syekh sufi atau murid bisa berafiliasi dengan banyak thurûq, sehingga menciptakan strukturstruktur yang luas dan kompleks. Karena itulah, struktur semacam ini mengandung potensi yang tinggi untuk memobilisasi massa dalam jumlah besar, dan sebagai konsekuensinya, maka tariqah dari waktu ke waktu menjadi dasar bagi gerakan sosial politik. ${ }^{5}$

Tasawuf dan tarekat mempunyai peranan yang penting memperkuat posisi Islam dalam negara dan masyarakat, serta pengembangan lingkungan masyarakat lebih luas. Beberapa peran itu di antaranya: (1) peranan sebagai faktor pembentuk dan mode fungsi negara; (2) sebagai petunjuk beberapa jalan hidup pembangunan masyarakat dan ekonomi; (3) sebagai benteng pertahanan menghadapi kolonialisasi Eropa; (4) peran tasawuf dan tarekat yang lebih menonjol adalah di bidang politik. Menurut Sartono Kartodirjo ${ }^{6}$ tarekat pada abad XIX M.

${ }^{5}$ Azyumardi Azra, Akar-akar Historis Pembaharuan Islam di Indonesia: Neo Sufisme Abad XI-XII H (Jakarta: Paramadina, t.th.), 3.

'Sartono Kartodirdjo, Pemberontakan Petani Banten (Jakarta: Pustaka Jaya, 1984). 
memainkan peran yang sangat penting dan berkembang pula menjadi golongan kebangkitan yang paling dominan. Artinya, walaupun pada mulanya tarekat merupakan gerakan kebangkitan agama, tarekat berangsur menjadi kekuatan politik keagamaan, bahkan menjadi alat paling efektif untuk mengorganisasikan gerakan keagamaan dan doktrinisasi cita-cita kebangkitan kembali.

\section{Gerakan Petani Banten}

Pemerintah Hindia Belanda dan umat Islam Indonesia, masing-masing mempunyai kepentingan berbeda-beda. Di satu pihak Pemerintah Hindia Belanda dengan segala daya berusaha memperkuat dan mempertahankan kekuasaannya, sementara di pihak lain umat Islam Indonesia berupaya pula untuk melepaskan diri dari kekuasaan tersebut.

Kenyataan menunjukkan bahwa hampir seluruh penduduk pribumi memeluk agama Islam. Suatu kenyataan yang memerlukan sikap serius bagi Belanda untuk menghadapinya, karena agama ini akan selalu menyadarkan pemeluknya bahwa mereka berada di bawah pemerintahan "kafir", dan bahwa cinta tanah air adalah termasuk sebagian dari iman.

Bagian kedua abad XIX merupakan suatu periode baru bagi imperialisme Belanda yang ditandai dengan politik kolonial yang berbeda sekali dengan politik kolonial yang telah dijalankan sebelumnya. Kalau kepentingan-kepentingan Belanda semula terbatas pada perdagangan, maka dalam periode ini Belanda mulai mengutamakan kepentingan politik. Belanda merebut supremasi perdagangan dari orang-orang Portugis, teristimewa perdagangan monopoli rempah-rempah.

Kepentingan agama dan ekonomi disingkat "Kristen dan Rempah-rempah", membawa orang Portugis ke Dunia Timur, tetapi tidak lama kemudian kepentingan perdagangan menjadi lebih utama daripada kepentingan agama, dan dengan kedatangan orang-orang Belanda perdagangan itu menjadi tujuan utama. Interpretasi ekonomis kerapkali dipergunakan untuk menerangkan ekspansi kolonial sebagai kepentingan kaum kapitalis yang akan menanamkan kelebihan modalnya atau kepentingan akan pasaran baru dan kepentingan mendapatkan 
sumber-sumber bahan-bahan mentah yang sangat esensial bagi industri-industri di tanah airnya. Semua fenomena politis itu bersumber pada sebab-sebab ekonomis atau sebab-sebab material.

Dalam pengamatan Sartono Kartodirdjo, ${ }^{7}$ tahun 1870 pada umumnya dianggap sebagai titik balik di dalam sejarah politik kolonial Belanda. Satu-satunya alasan adalah Undang-undang Agraria yang disahkan dan mulai berlaku pada tahun itu. Pengambilalihan tanah penduduk pribumi dilarang. Orang-orang asing diperbolehkan menyewa tanah pertanian dalam jangka waktu lima tahun. Ketentuan yang pertama dimaksudkan sebagai cara mencegah timbulnya kekuasaan yang akan merampas hak milik atas tanah secara tidak semena-mena.

Di sini, ide humaniter nampak jelas sekali. Tetapi ketentuan yang kedua bagaimanapun ditujukan untuk perusahaan, yaitu memberi jalan kepada pengusaha-pengusaha swasta untuk memakai tanah penduduk. Akan tetap,i tanah dan tenaga kerja merupakan satu kesatuan, kedua-duanya terjalin pada organisasi politik penduduk pribumi, sehingga mereka yang menguasai tanah itu dapat menggunakan tenaga penduduk secara sewenang-wenang, sebanyak yang dikehendakinya. Meskipun tenaga kerja harus diperoleh atas dasar kontrak, namun tuntutantuntutan yang melampaui batas tidak dapat dicegah, karena rakyat kecil tidak berdaya menghadapi kepala-kepala mereka atau pengusaha-pengusaha perkebunan Belanda. Sistem yang baru itu mempunyai akibat yang menguntungkan, akan tetapi mereka tidak dapat menduga konsekuensi-konsekuensi lainnya, bahwa akhirnya "kebebasan berusaha", sebagai cita-cita sosial dan ekonomi, hampir-hampir menjadi kata lain dari eksploitasi kapitalis.

Usaha Belanda mengonsolidasi kekuatannya mendapat perlawanan dari raja-raja Islam, dan di tingkat desa, daripara guru dan ulama Islam. Meskipun Belanda berhasil mengontrol sebagian besar daerah Nusantara yang ditaklukkannya, namun semangat melawan penjajah tetap berkibar di mana-mana; bahkan sejak abad XIX umat Islam Indonesia mendapatkan

7 Sartono Kartodirjo, Sejarah Pergerakan Nasional (Jakarta: Gramedia Pustaka Utama, 1999), 25. 
daya dorong, berkat semakin meningkatnya hubungan dengan Timur Tengah.

Menapaktilasi sejarah Banten, menurut A.H. Nasution, pada tahun 1682 Sultan Ageng Tirtayasa dari Banten mengerahkan tentaranya dalam usaha mengusir penjajah dari wilayahnya. ${ }^{8}$ Sementara, menurut Azra, Sultan Ageng Tirtayasa adalah penguasa besar terakhir kesultanan Banten. Di bawah pemerintahannya, Kesultanan mencapai masa keemasan; pelabuhannya menjadi pusat perdagangan internasional yang penting di Nusantara. Orang-orang Banten berniaga dengan para pedagang dari Inggris, Denmark, Cina, Indo-Cina, India, Persia, Filipina, dan Jepang. Kapal-kapal Kesultanan Banten berlayar di banyak perairan Nusantara, mewakili kekuatan dagang terakhir dari kerajaan-kerajaan Melayu-Indonesia.?

Sultan Ageng adalah musuh sengit Belanda. kenaikannya ke tahta membuka kembali pertentangan yang berlangsung lama antara orang-orang Banten melawan Belanda. Armada Sultan Ageng yang meniru Eropa, menyerang pos-pos Belanda di Sumatera. Sultan Ageng juga membuat Banten menjadi tempat perlindungan yang aman bagi para pejuang dari tempat-tempat lain di Nusantara dari peperangan melawan Belanda. Bagi Belanda yang pada waktu itu membentengi diri mereka di Batavia, Sultan Ageng merupakan penghalang besar dalam upaya perluasan wilayah mereka di Nusantara.

Dalam episode selanjutnya, pada tahun 1750-1753 terjadilah perang besar Banten yang dipimpin oleh Ratu Bagus Buang dan Kyai Tapa, dan pada tahun 1822 di Banten juga terjadi pemberontakan, sebelum terjadinya pemberontakan tahun 1888 .

Kondisi objektif masyarakat dunia khususnya negara berkembang, sebagian besar penduduknya adalah petani yang tinggal di daerah pedesaan. Gambaran sosial, ekonomi politik budaya di negara-negara berkembang adalah gambaran mengenai petani. Kajian petani pada masyarakat praindustri dapat memberi gambaran mengenai metode pertanian yang sederhana, kehidupan sosial ekonomi yang subsistem, serta harapan.

8 A.H. Nasution, Sekitar Perang Kemerdekaan Indonesia, Jilid I (Bandung, 1977), 32, 35.

9 Azyumardi Azra, Jaringan Ulama (Bandung: Mizan, 1994), 222. 
Beberapa contoh gerakan sosial petani adalah sebagai berikut: Gerakan petani Banten 1888; Pemberontakan Petani Cimareme, Garut 1919; Pemberontakan petani Ciomas, 1886; Peristiwa Gedangan 1904; Peristiwa pemberontakan Pak Jebrak di Brangkal, 1919; Gerakan petani Samin, 1917. pemberontakanpemberontakan yang besar jumlahnya itu telah terjadi di pulau Jawa, hanya dalam tahun 1844, 1847, 1860, 1868, 1871, dan 1874 sajalah tidak terjadi pemberontakan. Gerakan-gerakan dengan sifat yang khusus dilukiskan secara terpisah. Ini merupakan bahwa pemerintah kolonial sudah menyadari arti gerakan semacam ini.

Pemberontakan Petani Banten terjadi pada tahun 1888 di distrik Anyer, ujung barat laut Pulau Jawa. Menurut Sartono Kartodirjo meskipun pemberontakan ini berkobar dalam masa yang relatif singkat, tanggal 09-30 Juli, gejolak sosial yang mendahului pecahnya pemberontakan ini harus ditelusuri ke belakang, yakni ke awal 1870-an. Pemberontakan ini hanyalah salah satu dari serangkaian pemberontakan yang terjadi di Banten pada abad XIX, dan merupakan suatu contoh mengenai ledakan-ledakan sosial yang sedang melanda Pulau Jawa pada waktu itu. Catatan-catatan dari Kantor Kolonial mengungkapkan berbagai kebangkitan dan usaha-usaha pemberontakan kaum tani.

Gerakan-gerakan millenarian, suatu hal yang mengiringi keresahan dan kerusuhan sosial, muncul di berbagai bagian di Pulau Jawa. Sementara gerakan kebangkitan kembali agama menampakkan diri dalam bentuk sekolah-sekolah agama serta tarekat di seluruh Jawa, yang tumbuh bagai cendawan di musim hujan. Sesungguhnya, abad XIX merupakan masa keresahan sosial yang menyertai perubahan sosial, yang timbul sebagai dampak dari pengaruh Barat yang semakin besar. Kita dapat mengamati peningkatan modernisasi ekonomi dan politik. Seluruh transisi dari tradisionalitas ke modernitas.

Kebanyakan pemberontakan petani itu bersifat lokal dan terpisah-pisah. Para petani tidak tahu apa yang diperjuangkannya; secara samar-samar mereka memang berniat menggulingkan pemerintah, tetapi mereka tidak menyadari bahwa mereka sedang mengambil bagian dalam suatu gerakan 
sosial yang revolusioner. Tentu saja, tidak ada realisme dalam tujuan yang dikemukakan oleh para pemberontak itu.

Penjelasan gerakan-gerakan petani atau millenarisme dari segi bentrokan antara kekuasaan kolonial dan masyarakat tradisional, dapat ditemukan dalam banyak kajian. Penjelasan itu relevan untuk kajian ini karena mengacu pada kondisi-kondisi yang telah diciptakan oleh kolonialisme dan pada peristiwa-peristiwa, proses-proses dan kecenderungan-kecenderungan yang ikut membantu timbulnya aliran-aliran anti-Barat.

Terjadinya pemberontakan petani dapat dipandang sebagai gerakan protes terhadap masuknya perekonomian Barat yang tidak diinginkan dan terhadap pengendalian politik, dua hal yang merongrong tatanan masyarakat tradisional. Dengan berlakunya perekonomian uang, timbulnya buruh upahan dan ditegakkannya administrasi pusat, maka secara umum struktur ekonomi dan politik dan politik tradisional runtuh.

Terganggunya keseimbangan masyarakat tradisional telah menimbulkan frustrasi dan rasa tersingkir secara luas, dan perasaan-perasaan itu, jika dikomunikasikan, lalu berkembang menjadi keresahan dan kegelisahan yang meluas. Keadaan seperti itu akan meledak apabila di bawah suatu pimpinan yang mampu mengarahkan potensi agresif itu, dapat dipusatkan ke arah sasaran-sasaran tertentu yang dianggap bermusuhan atau menuju perwujudan gagasan-gagasan tentang millenarian. Di daerah-daerah yang peranan agamanya dominan, para pemimpin agama dengan mudah menempati kedudukan sebagai pemimpin dalam gerakan-gerakan rakyat dengan jalan mengungkapkan pesan millenarian mereka itu dengan istilah-istilah keagamaan. karena itu, gerakan-gerakan pemberontakan yang mereka lancarkan juga dapat dianggap sebagai gerakan keagamaan dan gerakan millenaristik.

Gerakan Petani Banten ini tidak termasuk pemberontakan yang besar jika dibanding dengan pemberontakanpemberontakan di negara-negara lain. Tetapi, pemberontakan yang dilakukan oleh gerakan ini merupakan gejala khas dari perubahan sosial dan perkembangan yang menyertainya. Yaitu, pergolakan yang sosial, yang begitu menonjol di Jawa pada abad XIX. Terkait dengan munculnya Gerakan Petani Banten, 
Snouck Hurgronje mengatakan; "Memang kekuasaan kita tidak akan mudah dirobohkan oleh suatu gerakan fanatik, Tapi huruhara setempat di Cilegon 1888 memang cukup serius".

Gerakan Petani Banten tidak saja diikuti oleh para petani an sich. Melainkan mereka yang berasal dari golongan penduduk pedesaan yang kaya dan terkemuka, para pemuka agama. Hanya dalam arti yang terbatas saja, pemberontakan yang terjadi dalam abad XIX di Indonesia dapat dikatakan sebagai pemberontakan petani yang murni dan sederhana.

Arti penting dari jenis pemberontakan ini bukanlah terutama karena dampaknya terhadap perkembangan politik, melainkan terletak dalam fakta bahwa kejadiannya yang endemik selama abad XIX dapat dipandang sebagai suatu manifestasi dari pergolakan agraris yang merupakan denyut arus bawah dari alur utama perkembangan politik pada periode "Pax Neerlandica". Sampai saat kejatuhan rezim Belanda, tampaknya ada rasa tidak puas yang meluas, yang senantiasa membara di bawah permukaan.

Kebanyakan penulis sekarang ini menganggap kebangkitankebangkitan itu sebagai ledakan fanatisme atau kerusuhan menentang pajak yang tidak disukai rakyat. Pada umumnya mereka merasa puas dengan mengemukakan faktor agama dan ekonomi sebagai penyebabnya. Sebenarnya, berbagai ketidakpuasan memuncak selama kerusuhan-kerusuhan itu, yaitu: ketidakpuasan di bidang ekonomi dan sosial, di samping agama dan politik. ${ }^{10}$

\section{Realisasi Sufisme dalam Gerakan Petani Banten}

Dalam masa penjajahan Belanda, Naqsyabandiyah merupakan penggerak pemberontakan di berbagai wilayah. Misalnya pemberontakan petani di Banten tahun 1888, pemberontakan di Sidoarjo tahun 1903, dan perang anti Bali di Lombok tahun 1894. Bagaimanapun, ajaran sosial dan sikap politik para pimpinan dan pengikut Naqsyabandiyah jelas sekali menunjukkan semangat kontrol sosial. Persis seperti disinyalir

${ }^{10}$ Sartono Kartodirdjo, The Peasants' Revolt of Banten in 1888: It's Condition, Course and Sequal (Den Haag: 1966). 
Fazlur Rahman, gerakan sufisme sangat tampak fungsi sosial dan protesnya. Menurutnya, motivasi agama bukanlah satu-satunya faktor langsung dalam pengembangan gerakan sufi. Fungsi sosial-politiknya, dan juga fungsi protesnya, bahkan lebih merupakan kekuatan dibandingkan dengan fungsi keagamaan. Dengan demikian, berdasarkan fakta-fakta seperti dicatat menunjukkan bahwa gerakan Petani Banten pada prinsipnya telah memfungsikan dirinya, tidak hanya sebatas gerakan ritual an sich.

Martin van Bruinessen menyatakan bahwa pemberontakanpemberontakan yang melibatkan tarekat ini terjadi dalam rentang waktu selama sekitar satu abad, sejak awal abad XIX sampai awal abad XX. Sebagian di antaranya adalah gerakan menentang masuknya pemerintah kolonial, sedangkan pemberontakan lain menentang peraturan-peraturan tertentu yang diterapkan pemerintah atas respons terhadap kemerosotan kehidupan ekonomi masyarakat dan penindasan. ${ }^{11}$

Pertumbuhan tarekat selama abad XIX terkait dengan mengikatnya jumlah orang muslim Indonesia yang menunaikan ibadah haji, yang menjadi lebih mudah setelah digunakannya kapal uap dan dibukanya terusan Suez. Banyak orang yang kembali dari berhaji sudah berbai'at menjadi pengikut suatu tarekat selama mereka menetap di Mekkah, dan sebagian di antaranya mendapatkan ijazah untuk mengajarkan berbagai amalan spiritual tarekat mereka. Mereka itulah yang kemudian menjadi guru-guru tarekat (mursyid) yang membawa dan menyebarkan tarekat ke wilayah-wilayah Indonesia.

Perjalanan ke Mekkah, selain memberikan kesempatan untuk memperdalam ajaran Islam, terutama ajaran-ajaran tasawuf, juga memberikan kepada mereka pengetahuan mengenai situasi dunia luar, dan banyak di antara mereka yang sangat menyadari adanya ancaman terhadap Islam karena adanya ekspansi kolonial. Demikianlah, perasaan anti kolonial dan tarekat seringkali menyebar secara bersama-sama, yang pastilah mempunyai andil dalam keterlibatan tarekat pada saat-saat tertentu sebagai sarana gerakan protes ekonomi dan politik.

${ }^{11 B r u i n e s s e n, ~ T a r e k a t ~ . . ., ~} 199$. 
Kenyataan di atas menimbulkan usaha untuk melarang pergi haji, sebab ibadah haji dinilai menyebabkan pribumi menjadi fanatik. Sementara itu, pemerintah Hindia Belanda mengeluarkan bermacam-macam peraturan yang membatasi dan mempersulit ibadah haji tersebut, sekalipun kemudian peraturan itu dicabut juga. Dalam situasi ini, menurut Aqib Suminto, ${ }^{12}$ Snouck Hurgronje tampil mendudukkan masalah hubungan hubungan antara "ibadah haji" dan "fanatik" ini. Menurut Snouck, koloni Jawa di luar negeri harus diawasi, dan ternyata kemudian, melalui konsul Belanda di Jeddah, semua sepak terjang para muqîmin itu diteliti. Bukan hanya di Jeddah, tetapi juga di Kairo, Kalkutta dan Singapura, Belanda memasang "radar" untuk mengawasi gerak-gerik pribumi ini.

Akhir abad XIX merupakan suatu periode kebangkitan kembali agama dan keadaan ini sedikit banyak berpengaruh terhadap munculnya pemberontakan petani di Banten. Kondisikondisi yang ada dalam lingkungan sosio-kultural di Banten telah mempersiapkan lahan yang subur bagi timbulnya gerakan kebangkitan kembali agama.

Menurut Aqib Suminto, Peristiwa Cilegon Banten 1888 tidak bisa dilepaskan dari latar belakang gerakan tarekat, karena banyak pelakunya tercatat sebagai pengikut tarekat. Bahkan menurut sinyalemen Residen Banten, seluruh pegawai sipil di sana, termasuk polisi, berada di bawah pengaruh para pemimpin agama yang notabene juga pengikut gerakan tarekat. Salah satu identitas gerakan semacam ini adalah xenophobia (anti orang asing) dan menggalakkan perang suci.

Di daerah itu memang telah terjadi beberapa kali pergolakan melawan Belanda, sehingga tidaklah mengherankan bila sesudah meletusnya peristiwa Cilegon Banten tahun 1888 itu gerakan tarekat mendapat perhatian khusus. Banyak anggota tarekat yang diusulkan oleh bupati agar dibuang, meskipun kadang-kadang alasannya tidak tertuju pada ajaran tarekat itu sendiri, melainkan pada organisasinya. Sampai tahun 1890 pun disinyalir, ketakutan terhadap peristiwa Cilegon ini masih cukup mendalam. ${ }^{13}$

12 Aqib Suminto, Politik Islam Hindia Belanda (Jakarta: LP3ES, 1996), 3.

13 Ibid., 66-7. 
Martin van Bruinessen ${ }^{14}$ mempunyai pemikiran yang sejalan dengan Aqib Suminto. Menurut Martin, pemberontakan petani, yang seringkali disertai harapan mesianistik, memang sudah biasa terjadi di Jawa, terutama pada abad XIX, dan Banten merupakan salah satu daerah yang sering berontak. Namun demikian, pemberontakan yang satu ini lebih mengguncang Belanda ketimbang yang lain-lainnya. Penumpasannya tidak terlalu merepotkan pihak Belanda, tetapi skala pemberontakan tersebut amat memprihatinkan. Ternyata tidak sedikit para pemimpin pemberontakan itu adalah para kyai dan haji-haji. Tidak sedikit kyai dan haji yang terlibat dalam pemberontakan itu adalah pengikut-pengikut tarekat Qadiriyah wa Naqsyabandiyah.

Yang dianggap pemimpin puncak dari tarekat ini adalah seorang Banten, Syaikh Abdul Karim, yang berdiam di Mekkah dan memperoleh kewenangan yang besar di kalangan orangorang Banten. Syaikh Abdul Karim sendiri kelihatannya tidak berminat dalam masalah politik tetapi khalifahnya, Haji Marzuki, yang diutus dari Mekkah ke Banten, dikabarkan lebih radikal dan lebih anti-Belanda. Pada keseluruhannya, tampaknya tarekat tidak memainkan peran yang khusus dalam pemberontakan, kecuali mungkin sebagai jaringan komunikasi. Yang pasti, menurut Martin, tarekat ini bukanlah penyebab atau yang mengatur pemberontakan tersebut. Tetapi, Belanda gelisah, dan banyak yang percaya bahwa tarekat-tarekat, khususnya Qadiriyah wa Naqsyabandiyah adalah organisasi rahasia yang bertujuan menumbangkan kekuasaan Belanda.

Berbeda dengan Aqib Suminto dan Martin van Bruinessen, Sayid Utsman bin Yahya, seorang teolog kenamaan di Batavia dan anggota kelompok Arab yang pro Belanda, menulis tentang Manhaj al-Istiqâmah fi al-Dîn bi al-Salâmah, menurutnya tarekat Islam sebagai pusat fanatisme irasional dan sejumlah pengikut tarekat pada Pemberontakan Petani Banten telah membunuh orang-orang Eropa dan orang-orang Indonesia yang bekerja sama dengan Belanda. Serangan balasan tentara Hindia-Belanda menelan korban jiwa hampir seratus orang Islam, tetapi Sayid Utsman menolak mengakui mereka sebagai syuhada' karena

\footnotetext{
${ }^{14}$ Bruinessen, Tarekat ..., 27.
} 
suatu alasan yang baik menurut pandangannya, mereka itu hanya korban kebodohan. ${ }^{15}$

Menurut pandangannya, mereka yang terlibat dalam pemberontakan Banten, terutama para pengikut (bukan) guruguru tarekat hanya didorong oleh fanatisme buta. Sehingga tindakan yang dilakukan mengabaikan pertimbanganpertimbangan rasional

Dalam catatan sejarah, menurut Aqib Suminto, ketika Snouck Hurgronje mengelilingi Jawa pada akhir tahun 1889, ia sangat terkesan oleh kenyataan bahwa di mana-mana pemerintah memburu guru agama, bahkan ada bupati yang begitu mudah melarang hampir setiap pengajaran kitab atau penyebaran tarekat. Tetapi atas saran K.F. Holler, agar setiap tahun diberikan daftar guru, supaya sedikit ada kesatuan dalam pengawasan. Snouck Hurgronje menulis surat kepada Menteri Jajahan Pleijte tanggal 4 Oktober 1913 bahwa Pemerintah kolonial Belanda pada dasarnya tidak menentang ajaran tarekat, tapi mencegah penggunaan pengaruh guru-guru tarekat untuk mengerahkan pengikutnya menentang pemerintah. ${ }^{16}$ Kebijakan yang diambil pemerintah kolonial Belanda tersebut di atas menggambarkan adanya kekhawatiran yang agak berlebihan terhadap tarekat. Sehingga kemudian kebijakan yang diambil adalah pengekangan terhadap tarekat. Kebijakan itu dilakukan di sebagian besar wilayah jajahan di mana terdapat tarekat.

Sebagaimana di tempat lain, di wilayah Cilegon Banten penguasa setempat kemudian menggunakan metode paling mudah untuk mengakhiri semua kesulitan, yaitu dengan melarang semua kegiatan tarekat. Kebijakan ini terbukti kurang efektif untuk menghentikan sama sekali kegiatan-kegiatan tarekat. Nampaknya kebijakan pelarangan dengan menerbit surat keputusan saja tidak mencukupi. Bahkan, menurut Snouck Hurgronje sebagai kebijakan yang kurang tepat, karena sebagaimana di dunia Islam lainnya, tarekat di kepulauan ini sangat kuat, sehingga tidak mungkin dihapus hanya dengan suatu surat keputusan.

${ }^{15}$ Kartodirdjo, The Peasants' ..., 160-1.

16 Suminto, Politik ..., 67. 
Mengambil pelajaran dari peristiwa pemberontakan Banten tersebut di atas, maka pemerintah kolonial Belanda atas saran Snouck Hurgronje, mengambil kebijakan yang yang lebih komprehensif untuk "membatasi" secara ketat pertumbuhan dan perkembangan tarekat di tanah air. Kebijakan itu diwujudkan dalam dua langkah, yaitu pertama, menghambat arus antitarekat, baik dari kalangan pejabat maupun dari golongan awam; kedua, mengadakan pengawasan ketat terhadap aktivitas gerakan tarekat itu sendiri.

Dengan kebijakan itu, pemerintah kolonial seperti melakukan tarik ulur terhadap keberadaan tarekat di seluruh wilayah jajahannya. Munculnya arus antitarekat di kalangan masyarakat pasca pemberontakan Banten berusaha diredam untuk kepentingan kolonial. Dengan meredam arus antitarekat, pemerintah kolonial ingin menegaskan bahwa mereka tidak melarang orang menjadi pengikut tarekat. Tetapi yang dilarang adalah menggunakan tarekat untuk kepentingan melawan dan memusuhi pemerintah kolonial Belanda. Dengan kebijakan ini pemerintah kolonial Belanda sekaligus membatasi ajaran Islam pada aspek-aspek ritual-personal semata. Kaum muslim bebas menjalan ajaran agama yang diyakininya sepanjang ridak mengusik kekuasaan pemerintah kolonial. Untuk menjamin efektivitas kebijakan di atas, pemerintah kolonial Belanda mengawasi secara ketat aktivitas tarekat. Pengawasan ini dimaksudkan untuk mencegah sedini mungkin benih-benih gerakan sosial pada tarekat sekaligus memastikan para pengikut tarekat hanya berhenti pada aktivitas ritual-personal.

\section{Catatan Akhir}

Peranan penting sufisme dalam kehidupan social masyarakat ternyata tidak hanya ditunjukkan pada kemampuannya menumbuhkan sikap hidup yang pasif. Dalam beberapa kasus menunjukkan bahwa sufisme (tarekat) ternyata juga mampu mendorong penganutnya untuk bersikap dinamis. Dalam konteks Indonesia, tarekat mengambil bagian dalam pemberontakan anti kolonial selama akhir abad XX dan awal XX. Salah satu pemberontakan yang paling besar terhadap 
pemerintah Belanda terjadi di Banten (Jawa Barat) pada tahun 1888.

Gerakan Petani Banten ini tidak termasuk pemberontakan yang besar, jika dibandingkan dengan pemberontakanpemberontakan di negara-negara lain. Tetapi pemberontakan yang dilakukan oleh gerakan ini merupakan gejala khas dari perubahan sosial dan perkembangan yang menyertainya, yaitu pergolakan sosial yang begitu menonjol di Jawa pada abad XIX.

Gerakan Petani Banten tidak saja diikuti oleh para petani an sich, melainkan mereka yang berasal dari golongan penduduk pedesaan yang kaya dan terkemuka, para pemuka agama. Tidak sedikit kyai dan haji yang terlibat dalam pemberontakan itu adalah pengikut-pengikut tarekat Qadiriyah wa Naqsyabandiyah. Namun demikian untuk membuktikan apakah ajaran-ajaran tarekat, khususnya tarekat Qadiriyah wa Naqsyabandiyah memang member dorongan kepada para pengikutnya untuk melakukan gerakan-gerakan perlawanan terhadap pemerintah colonial, maka dibutuhkan kajian-kajian tentang keberadaan tarekat tersebut di wilayahwilayah lainnya, bukan hanya di Banten. Wa al-Lâh a lam bi al-shawâb.

\section{Daftar Pustaka}

A.H. Nasution, Sekitar Perang Kemerdekaan Indonesia, Jilid I (Bandung: 1977).

Aqib Suminto, Politik Islam Hindia Belanda (Jakarta: LP3ES, 1996).

Azyumardi Azra, Akar-akar Historis Pembaharuan Islam di Indonesia

Neo Sufisme Abad XI-XII H (Jakarta: Paramadina). , Jaringan Ulama (Bandung: Mizan, 1994).

Cyril Glasse, Ensiklopedi Islam (Jakarta: Rajawali Press, 2002).

Martin van Bruinessen, Kitab Kuning: Pesantren dan Tarekat (Bandung: Mizan, 1994).

Sartono Kartodirdjo, Pemberontakan Petani Banten (Jakarta: Pustaka Jaya, 1984). , The Peasants' Revolt of Banten in 1888: It's Condition, Course and Sequal (Den Haag: 1966). 
, Sejarah Pergerakan Nasional (Jakarta: Gramedia Pustaka Utama, 1999).

Seyyed Hossein Nasr, Tasawuf Dulu dan Sekarang (Jakarta: Pustaka Firdaus, 1994).

Zulkifli, "Pemeliharaan dan Kesinambungan Tradisi Tasawuf Tarekat Sammaniyah di Palembang", Makalah disampaikan pada Pertemuan Jaringan Pusat Penelitian IAIN/STAIN tanggal 18-19 Juni 1997 di IAIN Raden Fatah Palembang. 